\title{
Samuel Kahn*
}

\section{Defending Kant's conception of matter from the charge of circularity}

DOI 10.1515/kant-2017-0017

\begin{abstract}
In the Metaphysical Foundations of Natural Science (MFNS) Kant develops a conception of matter that is meant to issue in an alternative to what he takes to be the then reigning empiricist account of density. However, in recent years commentator after commentator has argued that Kant's attempt on this front is faced with insuperable difficulties. Indeed, even Kant seems to have thought that his theory of density is circular, and some of these commentators argue that this is, at least in part, what spurred Kant on to develop the theory of matter found in the Opus Postumum. Against this growing tide (and even, it seems, against Kant himself) I defend Kant's theory of density. I shall not take a stand on whether the circularity problem played a role in the development of the Opus Postumum theory of matter - my point is simply that if the circularity problem was the sole trigger for that move, then the move was unwarranted.
\end{abstract}

Keywords: Kant; Metaphysical foundations of natural science; density; circularity problem; theory of matter

\section{Introduction}

In the Metaphysical Foundations of Natural Science (MFNS) Kant develops a conception of matter that is meant to issue in an alternative to what he takes to be the then reigning empiricist account of density. ${ }^{1}$ However, in recent years commentator after commentator has argued that Kant's attempt on this front is faced with insuperable difficulties. Adickes argues that the MFNS theory of density involves Kant in a vicious circle; Tuschling argues that the circle is part of what led Kant to abandon the theory of matter developed in the MFNS; Förster argues that recognition of this circularity played a significant role in Kant's development

1 It was also, of course, intended to be an alternative to the theory Kant articulated in his earlier Physical Monadology (1756).

*Kontakt: Samuel Kahn, Cavanaugh Hall, 344A, 425 University Blvd, IUPUI, Dept. of Philosophy, Indianapolis, IN, U.S.A.; sjmkahn@gmail.com 
of the project now known as the Opus Postumum; and Westphal argues that the circularity problem serves to demonstrate the "untenability of Kant's metaphysical method" and therefore helps to explain "the radical revision of the relation between mathematics and metaphysics Kant undertakes in his opus postumum."2 Indeed, even Kant seems to think that his theory of density is circular: as noted by all of these commentators, in correspondence with one of his former students Kant declares that this theory "seems to lead however to a circle out of which I am not able to come."3

Although (as will be seen below) Kant's own description of the circle is somewhat less than perspicuous, according to these commentators the problem lies on the surface: on Kant's account, there is an attractive force that depends on mass even though density depends on that same attractive force. Because density is a function of mass (density is mass over volume), this entails that attractive force depends on mass while mass (in a fixed volume) depends on attractive force. ${ }^{4}$

2 Adickes argues for this in volume 14 of the Academy edition of the works of Kant. See esp. Refl, AA 14: 338.04-05: "It is in fact a circle in which Kant is moving, and indeed a circle from which there is no escape" (my translation). It is notable that Adickes later retracts his charge of circularity: in Adickes, Erich: Kant als Naturforscher, Berlin 1924, he refers back to his earlier comments and says that after thinking the issue through again, it appears to him that "the circle lies more in the words" (vol. I, 215, my translation). However, this retraction is dampened by the fact that even in his 1924, Adickes still thinks that Kant's comments about circularity are tracking a deep problem with Kant's theory of matter, a problem which turns out to be similar to the problems raised by other researchers under the guise of the circularity problem (see esp. Adickes, 1924, section 86, vol. I, 215-218). Tuschling's argument can be found in Tuschling, Burkhard: Metaphysische und Transzendentale Dynamik in Kants Opus Postumum. Berlin 2012, esp. $46 \mathrm{ff}$. Förster's argument can be found in Förster, Eckart: Kant's Final Synthesis, Massachusetts 2000, esp. 33-37; he explains how Kant's later theory of matter (the Opus Postumum theory of matter) gets around the circularity problem on $44 \mathrm{f}$. For an earlier version of this argument, see Förster, Eckart: “Kant's Selbstsetzungslehre”, in Kant's Transcendental Deductions, edited by Eckart Förster, Stanford 1989, 217-238, esp. 223f. Westphal's argument can be found in Westphal, Kenneth: “Kant's Dynamic Constructions”, in Journal of Philosophical Research XX, 1995, 381-429, esp. section V. A later version of this argument can be found in Westphal, Kenneth: Kant's Transcendental Proof of Realism, Cambridge 2004, chapter 5, esp. sections 49-51. The quotation from Westphal in the text above is from Westphal, 2004, 6. As will become evident below, although I disagree with them on many points, I am especially indebted to the detailed and incisive discussions of this topic in Förster and Westphal.

3 "Aber das führt doch gewissermaaßen auf einen Cirkel aus dem ich nicht herauskommen kan" (Br, AA 11: 377.02-03). My translation differs only in very minor detail from Westphal's (see Westphal, 2004, 192).

4 In Pollok, Konstantin: Kants “Metaphysische Anfangsgründe der Naturwissenschaft”. Hamburg 2001, Pollok summarizes the problem as follows: the force of attraction "on the one side should be a constitutive element of the concept of matter and on the other side should be a property of matter which is proportionate to the quantity of matter" (262n461, my translation). 
The way out of the circle is evidently to introduce an additional attractive force into the theory of matter so that attractive force1 depends on mass while density depends on attractive force2.

Against this growing tide (and even, it seems, against Kant himself) I defend Kant's theory of density. I argue that the suspicion of a circle results from a confusion of logical relations with causal conditions, and I argue that even Kant seems to have been taken in by this confusion. I shall not take a stand on whether the circularity problem played a role in the development of the Opus Postumum theory of matter-my point is simply that if the circularity problem was the sole trigger for that move, then the move was unwarranted.

Accordingly, the paper is divided into five sections. I begin by setting out the preliminaries of Kant's dynamical theory of matter: repulsive force, infinite divisibility, attractive force and penetrating force. I argue that one of Kant's main goals in the MFNS (one that ultimately threatens to upend his theory of density) is to give a firmer foundation to Newtonian universal gravitation, and I pose objections to these building blocks of Kant's theory before arguing that in each case Kant is able to get around them (although perhaps not entirely unscathed). This will help to show how Kant's thought might have been spurred on by his study of Newton. Once the groundwork has been laid in this way, I turn to and try to defuse the circularity problem, which, again, arises in part from Kant's attempt to replace empiricist corpuscular accounts of density.

\section{Section 1: repulsive force}

Kant claims that matter is "the movable insofar as it fills a space"5 through "the repulsive forces of all of its parts." ${ }^{6}$ By "filling," Kant means resisting mechanical penetration, where this means matter's resisting when "the space of its own extension is to be diminished." Resisting mechanical penetration is opposed to mechanical resistance (inertia), which occurs when an object is "moved itself." For example, the air in an air-pump barrel exerts resistance in all directions as the piston is compressed and thus resists mechanical penetration. By way of contrast,

5 “Materie ist das Bewegliche, sofern es einen Raum erfüllt" (MAN, AA 04: 496.06). All of my MFNS translations are from the Cambridge Texts in the History of Philosophy edition.

6 "Die Materie erfüllt ihre Räume durch repulsive Kräfte aller ihrer Theile" (MAN, AA 04: 499.06-07).

7 “[...] wenn bloß der Raum ihrer eigenen Ausdehnung verringert werden soll” (MAN, AA 04: 497.01-02).

8 “[...] selbst bewegt werden [...]” (MAN, AA 04: 496.22-23). 
when one billiard ball hits another, the latter will resist being "driven out of its place," "where the "place" of a spherical body such as a billiard ball is its "central point." ${ }^{10}$ Dynamical resistance therefore causes a diminution in the motion of whatever movable is striving to penetrate into a filled space, and because Kant argues that the motion of a movable can be diminished only by a composition of its original motion with a motion in the opposite direction, he concludes that dynamical resistance, through which matter fills space, is a moving force (quite literally a cause of motion).

In the context of his discussion of dynamical resistance, Kant distinguishes between two possible forces: attractive and repulsive. Attractive force is that by which a matter "can be the cause of the approach of others to it"11 and repulsive force is that by which a matter "can be the cause of others removing themselves from it." ${ }^{12}$ Thus, in the paragraph above, matter fills space through the repulsive forces of all of its parts. That is, it fills space insofar as it exerts dynamical resistance to mechanical penetration, which just is repulsive force. The attribution of repulsive force to matter is analytic: matter is the moveable insofar as it fills a space; to fill a space is to resist penetration; penetration is a motion, and therefore to resist penetration is to cause a diminution in motion; something that causes a diminution in motion toward a body is a repulsive force; thus, matter has repulsive force. This repulsive force is original in the sense that it is an essential property of matter: if $\mathrm{X}$ does not have repulsive force, then $\mathrm{X}$ does not fill space and therefore is not matter. ${ }^{13}$

However, this argument has faced objections ever since the earliest reviews of the MFNS. For example, in 1786 an anonymous reviewer concedes that "a body which is in motion certainly remains in one and the same place in absolute space if the plane upon which it lies is moved in exactly the opposite direction with the same speed," but then goes on to ask whether "every remaining at a place must be thought in this way," before posing a rhetorical question: "Must one think to oneself [there is] a moving power in a wall, because one cannot go further through the wall?"14 More recently, in Kant's Transcendental Proof of Realism Westphal argues:

9 “[...] aus ihrem Orte getrieben [...] werden” (MAN, AA 04: 496.22-23).

10 "Mittelpunkte" (MAN, AA 04: 482.29).

11 "Anziehungskraft ist diejenige bewegende Kraft, wodurch eine Materie die Ursache der Annäherung anderer zu ihr sein kann” (MAN, AA 04: 498.17-19).

12 "Zurückstoßungskraft ist diejenige, wodurch eine Materie Ursache sein kann, andere von sich zu entfernen" (MAN, AA 04: 498.21-22).

13 Kant also suggests that repulsive force is original in the sense that it can be derived ("abgeleitet”) from no other property of matter (MAN, AA 04: 500.06).

14 This review appeared originally in the Göttingische Anzeigen von gelehrten Sachen. As noted 


\begin{abstract}
Kant's proof does nothing to advance his case against corpuscularism, which accounts for ... resistance by ascribing impenetrability to matter. Kant is right that the law of contradiction does not repel any material bodies (M 498.3-5). However, according to corpuscular doctrine, what would violate the law of contradiction is a piece of matter that lacks impenetrability; impenetrability itself is a physical property of matter, and this property of a material body (not the law of noncontradiction) resists the intrusion by other bodies into the space it occupies. Kant's argument does nothing to show that what repels the penetration of a body into the space occupied by another body is its intrinsic moving (repulsive) force rather than any kind of intrinsic impenetrability. ${ }^{15}$
\end{abstract}

I contend that both the anonymous reviewer's and Westphal's objections fall wide of the mark. They will be addressed in turn.

The trouble with posing a rhetorical question is that sometimes doing so backfires. That, I think, is exactly what happens in the case of the anonymous review from 1786. The simple answer to the reviewer's question about whether a moving force must be ascribed to a wall because one cannot walk through the wall is "yes." As noted above, for a body to resist mechanical penetration (to fill a space) is for that body to exert a repulsive force on that which is attempting to penetrate it. This is an analytic truth: repulsive force just is that whereby a body fills a space. The more complicated answer would involve the standard model of mechanics that is taught in introductory physics courses throughout the world and, in particular, the use of free body diagrams. The irony is that what the anonymous reviewer takes to be so absurd is now referred to as the "normal" force. ${ }^{16}$

The problem with Westphal's objection is subtler because it involves a slight misreading of the text. Westphal is absolutely right that the central issue in this part of the Dynamics is to account for matter's resistance to penetration. He is also absolutely right to take corpuscular accounts of matter to be one of Kant's main targets in the Dynamics. Where Westphal goes wrong is in thinking that Kant takes himself to have dismantled corpuscular accounts in the section of

by Westphal (1995, 420n120), it is reprinted in Rezensionen zur Kantischen Philosophie 1781-87, ed. Albert Landau, Bebra 1991, vol. 1, 479-481. The quotations in the text above are taken from 480 of Landau. The review is quite well known: it is quoted in Tuschling, 1971, $47 \mathrm{f}$.; Förster, 2000, 37 f.; and Westphal, 2004, 189 (and Westphal, 1995, 394). The translation in the text above differs from Westphal's and Förster's only in minor details.

There is some dispute about the author of the review. Tuschling argues that the author was Mayer (Tuschling, 47-49). But Förster asserts (on the basis of Fambach's discussion in his 1976 Die Mitarbeiter der Göttingischen Gelehrten Anzeigen, 1769-1836) that the author was Kästner (Förster., 2000, $37 \mathrm{f}$. and 183n17). I do not take a stand on this question here.

15 Westphal, 2004, 188.

16 The irony of course is mitigated by the fact that in this context, "normal" connotes "perpendicular.” 
text to which he (Westphal) refers his readers, the section of text worked through above. The best evidence that Kant does not take his account of repulsive force (as that whereby matter fills a space) to rule out corpuscularism comes from the fact that Kant puts forth an explicit argument against corpuscularism 4 Academy pages later in remarks 1 and 2 to Explication 4. In these later passages Kant clearly takes corpuscularism to be a live option; it is a position that still must be refuted. Thus, Kant does not seem to think he has offered good grounds yet for doubting corpuscularism. It follows that although Westphal is right that Kant has not shown yet why one ought to subscribe to a dynamic rather than a corpuscular theory of matter, he (Westphal) is wrong in thinking that this is in any way problematic for Kant. It is instructive to look at Kant's actual argument for this point.

Kant begins explication 4 by distinguishing between absolute and relative impenetrability (MAN, AA 04: 501.29-502.03). Absolute impenetrability is the kind of impenetrability presupposed by the corpuscular theory of matter: according to corpuscularism, the basic atoms that make up matter are not capable of any compression (and hence are absolutely impenetrable). Insofar as a body can be compressed (as when, e. g., a sponge is squeezed) this is because there are empty spaces between the basic atoms (in the corpuscular story). If those empty spaces ever could be eliminated, the body would cease to be compressible. This is in contrast with Kant's dynamic account of matter, according to which matter's impenetrability rests on repulsive force increasing in proportion to the degree of compression (hence relative impenetrability). In other words, on the dynamic theory of matter, the more matter is compressed, the more it resists compression (like a spring). These contrasting stories about compression (used here to illustrate the distinction between absolute and relative impenetrability) will be returned to later. For now, the focus is on the following question: why is corpuscular absolute impenetrability ("intrinsic impenetrability" in Westphal) problematic on Kant's account? To understand this, one must turn to the remarks to explication 4.

In the first remark, Kant argues as follows:

[...] expanding force first makes matter itself possible, as an extended thing filling its space. But this force has a degree that can be overpowered, and thus the space of its extension can be diminished, that is, penetrated up to a certain amount by a given compressing force, but only in such a way that complete compression is impossible, because this would require an infinite compressing force; therefore the filling of space must be viewed only as relative impenetrability. ${ }^{17}$

17 “[...] die ausdehnende Kraft macht sie selbst als ein Ausgedehntes, das seinen Raum erfüllt, allererst möglich. Da aber diese Kraft einen Grad hat, welcher überwältigt, mithin der Raum 
The basic point Kant is making here is that the repulsive force presupposed by absolute impenetrability (and, thus, by corpuscular theories of matter) would have to be infinite. It would have to be infinite because a compressive force of any magnitude could be applied to an absolutely impenetrable body with no effect. But Kant thinks that an infinite force is absurd:

[...] beyond any given force, a greater force must be thinkable, for that force beyond which no greater is possible would be one whereby an infinite space would be traversed in a finite time (which is impossible). ${ }^{18}$

Herein lies the core of Kant's objection to corpuscularism. Corpuscularism presupposes absolute impenetrability; absolute impenetrability presupposes an infinite repulsive force; an infinite repulsive force would be one whereby an infinite space would be traversed in a finite time; but it is impossible to traverse an infinite space in a finite time. ${ }^{19}$ This is why Kant concludes (in the second remark to Explication 4) that absolute impenetrability is an "occult quality." ${ }^{20}$ This is also why Kant argues that "the principle of noncontradiction does not repel a matter advancing to penetrate into a space where another is found."21 The idea is that the corpuscular appeal to solidity involves a covert appeal to repulsive force (when it is analyzed correctly), but corpuscularism is unable to offer any physical explanation for the extension of bodies because any such explanation would rely on something impossible: an infinite force. Kant's dynamic theory of matter, by way of contrast, is able to offer such an explanation. It follows that if my reading is correct, then Westphal's criticism of Kant's argument against corpuscularism

der Ausdehnung verringert, d.i. in denselben bis auf ein gewisses Maß von einer gegebenen zusammendrückenden Kraft eingedrungen werden kann, doch so, daß die gänzliche Durchdringung, weil sie eine unendliche zusammendrückende Kraft erfordern würde, unmöglich ist: so muß die Erfüllung des Raums nur als relative Undurchdringlichkeit angesehen werden.” (MAN, AA 04: 502.12-19)

18 "Über jede gegebene Kraft muß eine größere gedacht werden können, denn die, über welche keine größere möglich ist, würde eine solche sein, wodurch in einer endlichen Zeit ein unendlicher Raum zurückgelegt werden würde (welches unmöglich ist)” (MAN, AA 04: 499.20-23).

19 Leibniz also opposed the possibility of absolute impenetrability: according to Leibniz, if absolutely impenetrable bodies collided, they would change velocity instantaneously, but such an instantaneous change in velocity would violate the principle of continuity. For a helpful discussion of this point, see Garber, Daniel: "Leibniz: physics and philosophy”. In The Cambridge Companion to Leibniz. Ed. Nicholas Jolley. Cambridge 1995, 270-352, esp. $322 \mathrm{f}$.

20 "[...] qualitas occulta" (MAN, AA 04: 502.22).

21 "Allein der Satz des Widerspruchs treibt keine Materie zurück, welche anrückt, um in einen Raum einzudringen, in welchem eine andere anzutreffen ist” (MAN, AA 04: 498.03-05). 
does not connect because Westphal focuses on Kant's introduction of repulsive force rather than on Kant's remarks about the magnitude of this force.

\section{Section 2: infinite divisibility}

Kant uses his argument about repulsive force to ground the claim that "matter is divisible to infinity." 22 Kant says that "the concept of substance means the ultimate subject of existence, that is, that which does not itself belong in turn to the existence of another merely as a predicate." 23 What Kant means by this can be explained by analogy: a substance is a bit like a coat hanger, and predicates are the coats that are put on it. Without the coat hanger, there would not be anything on which to hang the predicates (the coats). Moreover, hanging a coat hanger on a coat or on another coat hanger does not work very well. (The analogy is of course imperfect. But hopefully the idea is clear.) Just so, although with regard to the purely logical use of the understanding it might make sense to say, "some divisible is a body," once a body out there in the world has been subsumed under the concept of substance it may be seen that the "correct" way to think about this is "that [body] is divisible."24

The reason this is important here is that Kant thinks there can be no exercise of the powers of causality, action or force without a substance on which to "hang" them. ${ }^{25}$ The basic argument seems to be as follows: there is action (resistance to mechanical penetration); action presupposes force (repulsive force); a force is a causal power; there can be no causal power where there is no substance. Material substance is then defined as "that in space which is movable in itself."26 Thus, because "in a space filled with matter, every part of it contains repulsive force,

22 "Die Materie ist ins Unendliche theilbar" (MAN, AA 04: 503.21).

23 "Der Begriff einer Substanz bedeutet das letzte Subject der Existenz, d. i. dasjenige, was selbst nicht wiederum blos als Prädicat zur Existenz eines anderen gehört” (MAN, AA 04: 503.05-07).

24 Paraphrasing Kant's remarks at KrV, B 128-B 129.

25 Kant exploits the connection between causal efficacy and substance in more ways than one. As noted above, in the MFNS he argues that there can be no causal efficacy without substance. However, in the Critique of Pure Reason Kant interprets Newtonians as taking space and time to be causally inert substances in which all causally active substances exist, and he concludes that this conception must be wrong because substance without causal efficacy is absurd (KrV, A 39/B 56).

26 "Materielle Substanz ist dasjenige im Raume, was für sich, d.i. abgesondert von allem anderen, was außer ihm im Raume existirt, beweglich ist” (MAN, AA 04: 502.31-33). 
so as to counteract all the rest in all directions, and thus to repel them and to be repelled by them,"27 every part of a filled space has material substance in it.

The idea that when matter fills a space there is material substance everywhere is important to Kant. ${ }^{28}$ He uses it to oppose the corpuscular theory of density, which, as noted above, presupposes the existence of empty spaces between absolutely impenetrable atoms. However, a full discussion of these issues can come only once Kant's theory of density has been discussed, which in turn requires a discussion of attractive force. So that is what is turned to now.

\section{Section 3: attractive force}

In section 1, Kant's argument for the claim that there is an original repulsive force was explored. However, Kant also thinks that there is an original attractive force. His argument for this runs as follows:

An essential moving force, whereby the parts of matter flee from one another, cannot, in the first place, be limited by itself, for matter is thereby striving instead continuously to enlarge the space that it fills; in the second place, [such a force] can also not be determined by space alone to a certain limit of extension, for the latter, although it can certainly contain the ground for the expansive force [i. e. pressure] becoming weaker in inverse proportion to the increase of volume of an expanding matter, can never contain the ground for this force ceasing anywhere, because smaller degrees are possible to infinity for any moving force. ${ }^{29}$

Based on this argument Kant concludes that if matter had merely repulsive forces, it would expand to infinity, "all spaces would be empty" and "no matter would

27 "In einem mit Materie erfüllten Raume aber enthält jeder Theil desselben repulsive Kraft, allen übrigen nach allen Seiten entgegen zu wirken, mithin sie zurück zu treiben und von ihnen eben so wohl zurückgetrieben" (MAN, AA 04: 503.30-32).

28 It should be noted that Kant does not distinguish between infinite divisibility (i.e., the property of density when applied to a number system like the rationals) and continuity (cf. Friedman, Michael: Kant's Construction of Nature. Cambridge 2013, 143n71). This has important implications for Kant, but none that is immediately relevant for my purposes.

29 "Nun kann eine wesentliche bewegende Kraft, dadurch die Theile der Materie einander fliehen, erstlich nicht durch sich selbst eingeschränkt werden, weil die Materie dadurch vielmehr bestrebt ist, den Raum, den sie erfüllt, continuirlich zu erweitern, zweitens auch nicht durch den Raum allein auf eine gewisse Grenze der Ausdehnung gesetzt werden; denn dieser kann zwar den Grund davon enthalten, daß bei Erweiterung des Volumens einer sich ausdehnenden Materie die ausdehnende Kraft in umgekehrtem Verhältnisse schwächer werde, aber, weil von einer jeden bewegenden Kraft ins Unendliche kleinere Grade möglich sind, niemals den Grund enthalten, daß sie irgendwo aufhöre" (MAN, AA 04: 508.18-27). 
exist at all." ${ }^{30}$ Because it is not the case that all spaces are empty and because matter does exist, it follows that all matter must have an original attractive force that counteracts this original repulsive force. Unlike the original repulsive force (the attribution of which to space-filling matter is analytic) the original attractive force is argued for on the grounds that it is necessary to make matter possible. Its attribution is therefore synthetic. ${ }^{31}$ But does this argument work? Has Kant succeeded in proving that there must be an original attractive force?

One problem that seems to arise here is that it is unclear why one repulsive mass of matter cannot be limited by more masses around it, which, in exerting their repulsive forces (which they need in order to keep the original mass from penetrating them) constrain the first mass. But Kant in fact considers this kind of objection explicitly, calling such a case one of mere "apparent attraction." ${ }^{2}$ He argues that this kind of objection will not work because "even these apparent attractions must in the end have a true one as their ground," ${ }^{33}$ for the outside masses must have an original attractive force in order to limit them. But I think that an objector can respond to this: it is unclear why there cannot then be, say, one mass without any attractive force surrounded by masses that do have attractive force. However, there seem to be two responses available here in defense of Kant.

First, Kant opens the proof of Proposition 5 by claiming that "impenetrability, as the fundamental property of matter, whereby it first manifests itself to our outer senses, as something real in space, is nothing but the expansive power of matter." ${ }^{34}$ Thus, perhaps Kant could respond by saying that here he is considering matter insofar as it manifests itself to one's outer senses: it is not obvious that this purely repulsive core of the matters that have both attractive and repul-

30 "Folglich würden bei blos repellirenden Kräften der Materie alle Räume leer, mithin eigentlich gar keine Materie dasein" (MAN, AA 04: 508.32-34). This argument tacitly rests on the assumption that space is infinite and unbounded. If space were finite and bounded (or - a possibility Kant does not consider - finite and unbounded (like the surface of a sphere)) then purely repulsive matter would not expand forever.

31 I am relying here on the first two sections of the System of All Principles in the Analytic of Principles of the Critique of Pure Reason, in which Kant sets out first the supreme principle of all analytic judgments and then the supreme principle of all synthetic judgments.

32 "Man kann diejenige Anziehung, die ohne Vermittelung der repulsiven Kräfte geschieht, die wahre Anziehung, diejenige, welche blos auf jene Art vor sich geht, die scheinbare nennen" (MAN, AA 04: 514.19-21).

33 "Aber selbst diese scheinbare Anziehungen müssen doch zuletzt eine wahre zum Grunde haben" (MAN, AA 04: 514.24-25).

34 "Die Undurchdringlichkeit als die Grundeigenschaft der Materie, wodurch sie sich als etwas Reales im Raume unseren äußeren Sinnen zuerst offenbart, ist nichts als das Ausdehnungsvermögen der Materie” (MAN, AA 04: 508.15-17, my emphasis). 
sive forces would constitute anything real in space if any of the boundary-matters were removed, for if they were removed then it would expand to infinity - it would have no determinate boundaries.

But this first response might seem unsatisfactory. The idea behind this argument is that because one would not sense a purely repulsive core immediately, it cannot be the case that such matter exists. But presumably even if one could not sense this purely repulsive core immediately, one still could sense it mediately. Indeed, given that Kant thinks that the original attractive force is always proportional to the quantity of matter (a point that will be addressed in the next section of this paper), it follows that any body that has a lower attractive force than one would expect based on some other measure of its quantity of matter (i.e., some method independent of measuring attractive force - e.g., measuring its quantity of motion at a given speed, as in the Mechanics (Explication 2, Proposition 1, MAN, AA 04: 537.24-26)) then would be a body that one would assume has some purely repulsive core. To put this in modern terms, the response about not being able to detect a purely repulsive core immediately is unsatisfactory because a purely repulsive core would be detectable mediately by (e.g.) determining whether gravitational mass is equal to inertial mass for a given body. But the response is unsatisfactory for another reason, too.

In the Remark to Proposition 5, Kant claims that the fact "that our senses do not allow us to perceive [...] attraction so immediately as [...] repulsion and resistance of impenetrability cannot yet provide a sufficient answer [as to why attractive force is not used as the first distinguishing mark of a matter]." ${ }^{35}$ Thus I think that arguing against the possibility of a purely repulsive core on the grounds that one's senses might not allow one to perceive this core immediately is a dead end in two ways. First, as noted in the previous paragraph of this paper, the argument does not seem to work: it leaves open the possibility of detecting the purely repulsive core mediately. Second, the argument faces exegetical problems. Based on this quotation from MAN, AA 04: 509.20-24, it seems unlikely that Kant would have made such an argument: he does not think that original attraction is any less fundamental a property of matter than original repulsion despite the fact that original attraction is sensed only mediately. By parity of reasoning, it follows that he would not think a purely repulsive core is in any way less fundamental on the grounds that it can be sensed only mediately. In sum, the argument is both

35 “[...] warum wird die letztere [viz., Undurchdringlichkeit] unmittelbar mit dem Begriffe einer Materie gegeben, die erstere aber nicht in dem Begriffe gedacht, sondern nur durch Schlüsse ihm beigefügt? Daß unsere Sinne uns diese Anziehung nicht so unmittelbar wahrnehmen lassen, als die Zurückstoßung und das Widerstreben der Undurchdringlichkeit, kann die Schwierigkeit noch nicht hinlänglich beantworten” (MAN, AA 04: 509.20-24). 
faulty and inconsistent with what Kant says elsewhere about a similar issue. But perhaps the following consideration will work.

The argument reproduced above (from the Proof of Proposition 5) is intended to prove only that some matter must have attractive force: "[h]ence there must somewhere be assumed an original force of matter acting in the opposite direction to the repulsive force [...] that is, an attractive force." ${ }^{36}$ That is, Kant has (to some extent) anticipated the objection discussed in the previous paragraphs of this paper and he concedes that the argument about matter expanding out to infinity without some attractive force to limit the inherent repulsive force shows only that there must be some limiting attractive force somewhere. To get to the conclusion that all matter has this attractive force, Kant goes on:

Yet since this attractive force belongs to the possibility of a matter as matter in general, and thus precedes all differences of matter, it may not be ascribed merely to a particular species of matter, but must rather be ascribed to all matter originally and as such. ${ }^{37}$

As can be seen from this passage, Kant rules out the possibility considered above (of a purely repulsive core) on methodological grounds. Kant's argument seems to be that because he is still considering matter merely qua matter and has not yet added any distinguishing marks to the concept (whereby one could distinguish one kind of matter from another) and because it already can be seen that this general concept of matter presupposes an attractive force to limit its essential repulsive force, it may be concluded that the attractive force must be attributed to all matter as such.

I do not find this argument particularly convincing. ${ }^{38}$ But it is useful to pause for a moment to explain why it is important for Kant, for that will help to show

36 "Also muß irgendwo eine ursprüngliche Kraft der Materie, welche in entgegengesetzter Direction der repulsiven, mithin zur Annäherung wirkt, d.i. eine Anziehungskraft, angenommen werden" (MAN, AA 04: 509.04-07, my emphasis).

37 "Da nun diese Anziehungskraft zur Möglichkeit einer Materie als Materie überhaupt gehört, folglich vor allen Unterschieden derselben vorhergeht, so darf sie nicht blos einer besonderen Gattung derselben, sondern muß jeder Materie überhaupt und zwar ursprünglich beigelegt werden" (MAN, AA 509.07-11).

38 That said, an alternative argument might be made on Kant's behalf. For example, it might be argued that because the repulsive core is moveable, it eventually would penetrate the "protective mantel" and disgorge to infinite, thus rendering any purely repulsive core unstable. This is bolstered by the fact that the net gravitational force on a point mass inside a uniform spherical shell is zero. One problem with this argument is that the boundary matters need not be limited to forming a uniform spherical shell. Moreover, the idea is not that these boundary matters would form an absolutely impenetrable wall but rather that the attractive forces from these boundary 
how he might respond to doubts about it. It also will help to set up the framework for the circularity problem toward which the paper is advancing.

As is now well known, despite the brilliant success of (at least parts of) Newton's Principia Mathematica, Newton and many of his followers viewed the action at a distance that his universal gravitation presupposed as occult. ${ }^{39}$ Action at a distance was to be explained away, and universal gravity was taken to be a derivative force that was reducible to contact forces by means of the all-pervading ether. However, toward the end of the Dynamics Kant points out that any such explanation would "set him [viz., Newton] at variance with himself." ${ }^{40}$ Kant's basic point is that Newton's argument in book III of the Principia Mathematica rests on applying the Third Law of Motion (the law of equal action and reaction) directly to gravitational forces and thus rests on the tacit assumption that gravity is not a derivative force but rather an instantaneous action at a distance force. ${ }^{41}$ From this arises one of Kant's main goals in the Dynamics: to show that Newtonian gravity, so far from being occult, is an essential property of matter.

To put this more simply, Kant wants to give Newton's Principia Mathematica a proper philosophical foundation. He wants to argue for universal gravity if not on pure a priori grounds, then on the minimal empirical assumption that matter is the moveable in space. This is why it is so important to him to prove that all matter has an essential attractive force: he wants to show that gravity is a universal force without appeal to experiment and induction. The first step in that direction is showing that an original attractive force is essential to all matter. The second step, which is going to be examined now, is showing that this original attractive force is proportional to the quantity of matter. After that, a potential response to lingering doubts about Kant's argument for original attractive force will be put forth.

matters would reach equilibrium with the repulsive forces from the core. If this is impossible, it is not (to me, anyway) obviously so.

39 Indeed, as Kant points out at MAN, AA 04: 515.28-30, in his work on Optics Newton claims not to take gravity for an essential property of bodies (for a more detailed discussion of this passage, see Friedman, Kant's Construction of Nature, esp. 210n173 and 221n196).

40 "[...] mit sich selbst uneinig macht” (MAN, AA 04: 515.32).

41 For a detailed exposition of this point as well as some additional historical background, see Friedman, Kant's Construction of Nature, 210-221. Perhaps this is the appropriate place for me to note that I am deeply indebted to Friedman, who provided feedback on an earlier (and significantly worse) version of this paper and from whose lectures and tutelage I have benefited immensely. 


\section{Section 4: penetrating force}

Given how little has been said thus far about the original attractive force, it is hard to see how Kant might argue that this force is always proportional to the quantity of matter in a given body and thus show that the original attractive force might be equated with Newtonian gravity. It is tempting to argue on Kant's behalf in the same way he argues for the claim that this force is essential to all matter: it is tempting to argue that because the original attractive force is attributed to all matter in general and prior to any differences in species of matter, when those differences are introduced, they must be irrelevant to the original attractive force. Thus, a given quantity of water matter must have the same attractive force as the same quantity of mercury matter (even though their densities and therefore volumes will differ).

However, that kind of argument is not available to Kant. In the Note to Proposition 6 Kant claims, "repulsive force and attractive force are equally essential to matter, not one more than the other." ${ }^{\text {"2 }}$ But at MAN, AA 04: 533.36-39 Kant claims that "repulsive force [...] has a degree that can be different in different matters." ${ }^{43}$ Thus it may be seen that although the original repulsive force is just as essential to matter as the original attractive force, Kant thinks the former can differ for different species of matter. It follows immediately (by parity of reasoning) that Kant ought not to take the mere fact that attractive force is attributed to matter in general as grounds for saying that it is always proportional to the quantity of matter irrespective of species. So what can his argument be?

Kant's argument comes in the Note to Explication 7: "the original attraction, which makes matter itself possible [...] [is] a penetrating force, and for this reason alone is always proportional to the quantity of matter." ${ }^{\prime 4}$ This is echoed in Proposition 8 Note 1, where Kant claims, "original attractive force, as a penetrating force exerted by all matter [...] [is] hence in proportion to its quantity." ${ }^{35}$ By a

42 "Also gehört die Zurückstoßungskraft zum Wesen der Materie eben so wohl wie die Anziehungskraft, und keine kann von der anderen im Begriff der Materie getrennt werden” (MAN, AA 04: 511.16-18).

43 “[...] die Materie nicht (wie blos mechanische Naturforscher annehmen) durch absolute Undurchdringlichkeit ihren Raum erfüllt, sondern durch repulsive Kraft, die ihren Grad hat, der in verschiedenen Materien verschieden sein kann” (MAN, AA 04: 533.36-39).

44 "So muß nun die ursprüngliche Anziehung, welche die Materie selbst möglich macht, gedacht werden, und also ist sie eine durchdringende Kraft und dadurch allein jederzeit der Quantität der Materie proportionirt” (MAN, AA 04: 516.18-21).

45 "Aus dieser ursprünglichen Anziehungskraft als einer durchdringenden, von aller Materie, mithin in Proportion der Quantität derselben ausgeübten und auf alle Materie, in alle mögliche Weiten ihre Wirkung erstreckenden Kraft [...]” (MAN, AA 04: 517.18-21). 
penetrating force, Kant means a force "whereby a matter can act immediately on the parts of others, even beyond the surface of contact" ${ }^{46}$ or, in other words, a force that is exerted immediately at a distance: "an immediate action of matter on other matter through empty space." ${ }^{47}$ Kant repeats this argument twice more in the text of the MFNS. In the General Remark to the Dynamics, Kant claims that the original attractive force rests solely on the "aggregate of matter in a given space" because

[...] through true attraction all parts of matter act immediately on every part of another, whereas through expansive force only those at the surface of contact act, so that it is all the same whether much or little of this matter is found behind that surface. ${ }^{48}$

Similarly, in the Mechanics, the chapter that follows the Dynamics, Kant argues as follows:

[...] in the case of [...] [attraction] the action of a matter with all its parts is exerted immediately on all parts of another, and hence (at equal distances) is obviously proportional to the aggregate of the parts $[. . .]^{49}$

It is worth trying to understand this argument because it is the last piece that needs to be put in place in order to understand the circularity problem. Kant's idea is that because attraction is a penetrating force, each part of the matter in a body exerts this force on each part of another - if there is less matter, the degree of attractive force will be lower and vice versa - and so the force is proportional to the quantity of matter.

However, this argument faces a problem analogous to the problem with Kant's argument for the claim that an original attractive force is essential to all matter: there might be different species of matter and thus different species of attractive force (and thus different constants of proportionality). To put this another way, when Kant says that attractive force is always proportional to quantity of matter, he is making a very specific claim: he is saying that active gravitational

46 “[...] wodurch eine Materie auf die Theile der andern auch über die Fläche der Berührung hinaus unmittelbar wirken kann [...]" (MAN, AA 04: 516.04-06).

47 "Die aller Materie wesentliche Anziehung ist eine unmittelbare Wirkung derselben auf andere durch den leeren Raum” (MAN, AA 04: 512.18-19).

48 "[...] durch wahre Anziehung alle Theile der Materie unmittelbar auf alle Theile der andern, durch expansive Kraft aber nur die in der Berührungsfläche wirken, wobei es einerlei ist, ob hinter dieser viel oder wenig von dieser Materie angetroffen werde” (MAN, AA 04: 524.07-10).

49 “[...] bei dieser Kraft die Wirkung einer Materie mit allen ihren Theilen unmittelbar auf alle Theile einer andern geschieht und also (bei gleichen Entfernungen) offenbar der Menge der Theile proportionirt ist [...]" (MAN, AA 04: 541.19-22). 
mass is equal to inertial mass, and his grounds for this assertion are (as has been seen) that gravity is a penetrating force. But both magnetic force and Coulomb force would count as penetrating forces in Kant's framework, and it is known that neither "magnetic mass" nor "electrical mass" is universally proportional to inertial mass. ${ }^{50}$ Sadly, it follows immediately that Kant's argument does not work.

Is this a deep problem for Kant? It does not seem like it. As has been seen above, the main resistance to Newton's theory of gravity was not to the idea that gravitational mass is equal to inertial mass or even to the idea that this apparent attractive force emanates from terrestrial and celestial bodies alike. The main resistance was to gravity's status as an action at a distance force, and it is exactly here that Kant wants to prop Newton up because he (Kant) saw that without this assumption, the Principia Mathematica is in for trouble. Kant might not have a satisfying argument for the claim that his universal attractive force is essential to all matter or for the claim that its magnitude is proportional to quantity of matter. But he could be satisfied in having shown that some original force of attraction must be presupposed somewhere on his account, for if this much is conceded, then he can rely on empirical results like Newton's famous Moon test to establish the rest. ${ }^{51}$ With this in mind, I turn to Kant's account of density and the circularity problem.

\section{Section 5: the circularity problem}

Kant's remarks about density are not limited to the MFNS. For example, in the Anticipations of Perception in the Critique of Pure Reason, Kant notes the following:

Nearly all natural philosophers, because they perceive a great difference in the quantity of matter of different kinds in the same volume [...] unanimously conclude from this: this volume [...] must in all matters, although in different measures, be empty. ${ }^{52}$

50 Kant knew this, too; see, e. g., his remarks about magnets at MAN, AA 04: 515.05-11.

51 Indeed, Kant points out at a number of points in the MFNS (especially in the General Remark to the Dynamics) that he is only laying the philosophical foundation for subsequent empirical work which will have to fill out the details of his theory. For example, consider the following suggestive passage: "everything, even universal attraction as the cause of weight, must be inferred from data of experience. Still less may such laws be attempted for chemical affinities otherwise than by way of experiments” (“[...] alles, selbst die allgemeine Attraction als Ursache der Schweren muß sammt ihrem Gesetze aus Datis der Erfahrung geschlossen werden. Noch weniger wird dergleichen bei den chemischen Verwandtschaften anders, als durch den Weg des Experiments versucht werden dürfen" (MAN, AA 04: 534.16-20)).

52 "Beinahe alle Naturlehrer, da sie einen großen Unterschied der Quantität der Materie von 
In this passage, Kant is setting up the empiricist account of density that he wants to attack. As noted above, on this account differences in density are explained by appeal to differences in volumes of empty space separating the absolutely impenetrable corpuscles that make up the matter of a body. Of course, as also noted above, Kant thinks that absolute impenetrability is problematic because it presupposes an infinite force. But absolute impenetrability is not the target here: the target here is the empty space explanation of density and compression.

Kant argues that this explanation presupposes that the real in space always has a uniform intensive magnitude. He does not want to prove otherwise in the Critique of Pure Reason: Kant does not want to show that the real in space does not always have a uniform intensive magnitude. But he does want to show that it is metaphysically possible to explain differences in density by appeal to differences in intensive magnitude of the matter filling space. One can understand this by means of an analogy. Consider a room that is filled with light. Adjusting a dimmer switch will determine the intensive magnitude of the light that fills the room. In just the same way, Kant imagines that the explanation of differences in density could appeal to a sort of "dimmer" version of matter instead of appealing to empty spaces between uniform matter:

[... on this alternative explanation of differences in density] although equal spaces can be completely filled with different matters in such a way that in neither of them is there a point in which the presence of matter is not to be encountered, nevertheless everything real has for the same quality its degree (of resistance or weight) which, without diminution of the extensive magnitude or amount, can become infinitely smaller until it is transformed into emptiness and disappears. ${ }^{53}$

But as noted in the introduction of this paper, Kant ultimately came to think that he did not have the requisite conceptual resources in the MFNS to offer a satisfactory version of this alternate "intensive magnitude" explanation of differences in density. Kant regarded his MFNS version of intensive magnitude density as circular, and he writes that the circle originates from the fact that "the attractive

verschiedener Art unter gleichem Volumen [...] wahrnehmen, schließen daraus einstimmig: dieses Volumen [...] müsse in allen Materien, obzwar in verschiedenem Maße, leer sein” (KrV, A 173/B 215). My translation differs only in minor details from the Guyer/Wood translation (which I have consulted extensively).

53 "Denn da sehen wir, daß, obschon gleiche Räume von verschiedenen Materien vollkommen erfüllt sein mögen, so daß in keinem von jenen ein Punkt ist, in welchem nicht ihre Gegenwart anzutreffen wäre, so habe doch jedes Reale bei derselben Qualität ihren Grad (des Widerstandes oder des Wiegens), welcher ohne Verminderung der extensiven Größe oder Menge ins Unendliche kleiner sein kann, ehe sie in das Leere übergeht und verschwindet” (KrV, A 174/B 216). The translation in the text above is taken from the Guyer/Wood translation. 
force (the universal, Newtonian [attractive force]) originally in all matter is the same and only the repulsive force is various in various [matters] and thus determines the specific difference in the density of the same." ${ }^{44}$ As also noted in the introduction of this paper, this formulation of the problem is somewhat less than perspicuous: at the very least, it needs unpacking.

Kant begins by noting that the original attractive force is the same in all matter; by this he must mean, as noted above, that gravitational mass is equal to inertial mass, an equivalence which, as also noted above, Kant argues for on the grounds that the original attractive force (here glossed as "Newtonian" [gravity]) is a penetrating force. He then argues that repulsive force varies in different kinds of matters ("repulsive mass" is not equal to inertial mass) and that repulsive force provides the key to understanding differences in density. Presumably the idea here is something like this. Given the same quantity of two different kinds of matter, M1 and M2, it follows that if there are no external penetrating forces and if M1 has a higher repulsive force per quantity of matter, then M1 will occupy more volume than M2 because M1 and M2 have the same degree of attractive force per quantity of matter. But if bodies are infinitely divisible, their density is determined not by how much empty space is in them (in between putatively corpuscular atoms) but rather by the degree of filling of that space: by the intensive magnitude of the forces in that space. Because M1 has the same amount of matter as M2 but in a greater volume, it has a lower density - or to put this in terms of force, the same extensive magnitude of attractive force is spread over a larger space, and thus the intensive magnitude of the attractive force at every point of that space is lower. This all seems relatively straightforward. If this were all there were to go on, it justifiably might be concluded that Kant's misgivings about his MFNS account were unfounded.

But this is not all there is to go on: other commentators have argued otherwise. Westphal formulates the circularity problem in two different passages, and they will be gone through in turn. Here is the first:

Kant's theory of the volume and density of matter as a function of the two basic forces entails that basic matters with different degrees of repulsive force must differ in volume! They would thus also differ in density because a stronger repulsive force would balance the same degree of attractive force within a smaller volume, but the total (scalar) quantity of these forces must be the same in all basic matters. Thus basic matters must all fill their respective spaces to the same (scalar) degree of intensity.

54 "[...] die Anziehung (die allgemeine, Newtonische,) ursprünglich in aller Materie gleich sey und nur die Abstoßung verschiedener verschieden sey und so den specifischen Unterschied der Dichtigkeit derselben ausmache" (Br, AA 11: 376.36-377.02). My translation differs only in minor details from Westphal's (Westphal, 2004, 192). 
This is absolutely not the result Kant sought or claimed. He claimed to have a theory according to which the same sized basic matters could differ in density ( $M$ 533.36-534.5). Kant's dynamic theory of matter thus leads quickly in the direction of either corpuscular atomism or physical monadology, both of which he sought to avoid. ${ }^{55}$

Westphal correctly concludes in the first sentence of this passage that on Kant's dynamic theory of matter, basic matters with different degrees of repulsive force must differ in volume. He arrives at this conclusion based on balancing considerations similar to the ones rehearsed above. However, Westphal argues in the first sentence of the second paragraph of this passage that this runs contrary to Kant's desired and stated theory: Kant claims to have developed a theory according to which the same sized basic matters could differ in density. The remedy for this deficiency is, according to Westphal, disastrous for Kant: Kant either must presuppose empty spaces in order to explain differences in density (and thus give up the fight against corpuscularism) or he must assume two different kinds of attractive force, one responsible for the constitution of matter and the other responsible for gravitational forces.

However, I think Kant's theory can withstand Westphal's attack in this passage. Westphal seems correct that Kant claims to have a theory according to which the same sized basic matters could differ in density. What Westphal seems not to notice is that if the same mass of different kinds of matter were to occupy different volumes (as in the example of M1 and M2 above) then it follows immediately that the same volumes of different kinds of matter will contain different quantities of mass. These are flipsides of the same coin: exactly the same reasoning that gets to one gets to the other. As for Westphal's claim that Kant's dynamic theory of matter collapses into either corpuscular atomism or physical monadology - Kant's precritical theory of matter, which has not been discussed in this paper due to space considerations-this is based on a subtle but nonetheless serious misunderstanding: Westphal thinks that on Kant's account, repulsive force "diminishes by the inverse cube of the distance." ${ }^{56}$ Let me try to explain why I think this is a misunderstanding.

Kant explains the diminution of the repulsive force in the following passage:

If it is said, therefore, that the repulsive forces of the parts of matter that immediately impel one another stand in inverse ratio to the cubes of their distances, this means only that they stand in inverse ratio to the volumes one imagines between parts that are nevertheless in immediate contact, and whose distance must for precisely this reason be called infinitely small, so as to be distinguished from every actual distance. ${ }^{57}$

55 Westphal, 2004, 193.

56 Westphal, 2004, 195.

57 "Wenn es also heißt: die zurückstoßenden Kräfte der einander unmittelbar treibenden Theile 
In this passage (which seems to be the one to which Westphal refers after claiming that repulsive force diminishes by the inverse cube of the distance) Kant claims that if he (Kant) says that repulsive force diminishes by the inverse cube of the distance, he is to be understood as saying that it diminishes by the inverse cube of infinitely small distances. ${ }^{58}$ As he states only one page earlier, "original attraction of matter would act at inverse ratio to the squares of the distance at all distances, the original repulsion in inverse ratio to the cubes of the infinitely small distances." ${ }^{59}$ This is not a mere figure of speech. By talking about infinitely small distances, Kant plainly means to be invoking the infinitesimals of Leibniz-Newton calculus: quantities smaller than any finite magnitude. ${ }^{60}$ This explains why Westphal is incorrect when he claims that Kant's dynamic theory of matter threatens to collapse into corpuscular atomism or physical monadology: according to both of those theories, basic matters have finite volume. But on Kant's dynamic account, basic matters have infinitesimal volume ${ }^{61}$ and in this way Kant's move to infinite divisibility may be appreciated: quantity of matter is no longer a function of the number of atoms or pieces of basic matter in a space. ${ }^{62}$ It is a function

der Materie stehen in umgekehrtem Verhältnisse der Würfel ihrer Entfernungen, so bedeutet das nur: sie stehen in umgekehrtem Verhältnisse der körperlichen Räume, die man sich zwischen Theilen denkt, die einander dennoch unmittelbar berühren, und deren Entfernung eben darum unendlich klein genannt werden muß, damit sie von aller wirklichen Entfernung unterschieden werde" (MAN, AA 04: 522.06-12).

58 Cf. Pollok, 2001, 262n462.

59 "Also würde die ursprüngliche Anziehung der Materie in umgekehrtem Verhältniß der Quadrate der Entfernung in alle Weiten, die ursprüngliche Zurückstoßung in umgekehrtem Verhältniß der Würfel der unendlich kleinen Entfernungen wirken” (MAN, AA 04: 521.04-07).

60 Indeed, at MAN, AA 04: 522.24-38 Kant points out that because his original repulsive force varies with the inverse cube of infinitely small distances, Newton's derivation of the Boyle-Mariotte law, which depends on a repulsion that varies with the inverse cube of distance (not infinitely small distance; distance), will not go through for his (Kant's) theory. This passage would be very difficult to understand if Kant is not interpreted in the way suggested above (pace Westphal). For a more detailed treatment of this point about the Boyle-Mariotte law, see Friedman, Kant's Construction of Nature, 230-232.

61 One might cash this out today using the surreal number system.

62 This also helps to explain why another of Westphal's criticisms fails. In "Kant's Dynamic Constructions," Westphal argues as follows:

Because matter is constituted by the balance of two opposed fundamental forces taken as radiating out from a common point, these basic matters must be spherical. Spheres do not conjoin into larger volumes without either large distortions or vacant interstices ...I do not see any way for Kant to avoid the result that his basic matters are spheres which either form interstices when compounded into larger volumes of matter, or which must undergo radical changes of shape when compounded. (Westphal, 1995, $400 \mathrm{f}$.) 
of the intensive filling of that space, which is determined by the balance of repulsive and attractive forces in the way described above.

However, perhaps sensing that something is awry with his first formulation of the circularity problem, Westphal puts that version down and articulates another version:

\begin{abstract}
Kant's problematic is set by the Newtonian physical principles whose metaphysical basis he sought to provide. According to Newtonian principles, the force of attraction is proportional to mass, and within a given volume mass is proportional to density. Hence, within a specific volume, the force of attraction must be a function of density. This conflicts with Kant's official view, according to which density is supposed to be a function of the balance of the two basic forces. ${ }^{63}$
\end{abstract}

Westphal argues that the circle arises because Kant is trying to provide a metaphysical basis for Newton's principles, according to which the force of gravitational attraction is proportional to mass, which in turn is proportional to density in a given volume. Because on Kant's view density is a function of the balance of repulsive force with attractive force, a vicious circle emerges: attractive force depends on mass (because attractive force is proportional to quantity of mass); density depends on attractive force (because volume occupied depends on balancing of attractive and repulsive force); but density just is mass per unity volume, so attractive force depends on mass depends (for a given volume) on attractive force.

Förster advances a similar interpretation of the circularity problem in Kant's Final Synthesis:

This identification [viz., that between original attractive force and Newtonian universal gravity], however, introduces a serious problem into Kant's theory. For gravitational mass is always proportional to the mass or, for a given volume, the density of a matter (4:514.33-35, 516.20). So the intensity of the attractive force must causally depend on density, and density must in turn be the effect of attraction ... ${ }^{64}$

\footnotetext{
Westphal repeats this line of criticism on 194 of his 2004 Kant's Transcendental Proof of Realism. The problem with Westphal's argument is that it (again) presupposes that repulsive force falls off with the inverse cube of radial distance rather than with the inverse cube of infinitesimal radial distance: if (as Kant argues) repulsive force falls off with the inverse cube of infinitesimal radial distance, then the "spheres" Westphal is talking about will be physical points. This serves also to undermine Westphal's remarks at 1995, 423n153 and 2004, 194n39. However, further discussion is beyond the scope of this paper.
}

63 Westphal, 2004, 195.

64 Förster, 2000, 35. 
Förster and Westphal both seem to think that the best solution to the circularity problem for Kant is to "distinguish gravitational attraction from the original force of attraction that, on his theory, combines with the basic repulsive force to determine the basic quantity of matter." ${ }^{55}$ This would help because it would break the circle: now gravitational force would depend on mass which in turn would depend on density, but density no longer would depend on gravitational force. Instead, density would depend on this alternative (original) attractive force.

One can begin to understand how to defuse the circularity problem by thinking about the way in which Kant introduces material substance in his discussion of infinite divisibility (section 2 above): the existence of forces logically presupposes the existence of a substance. This is not because the substance causes the force. This is because the force is a cause (of motion) and only a substance can be causally efficacious. Thus, having repulsive force and having attractive force are properties (or, more properly, powers), not effects, of a material substance. Thus, as was seen above (in section 4) Förster is absolutely right that on Kant's account, gravitational mass is always proportional to the mass or, for a given volume, the density of a matter. But this is strictly a mathematical relation and does not entail (pace Förster) that "the intensity of the attractive force must causally depend on density." Density causes no such thing. Indeed, to say that density is a cause of anything would be a category mistake on Kant's theory: density is not a substance and therefore cannot be causally efficacious. Strictly speaking, there is a material substance that has both a repulsive force (established, as was seen in section 1 above, by virtue of the fact that the matter fills space) and an attractive force (established, as was seen in section 3 above, by virtue of the fact that without this force the matter would expand to infinite); the repulsive force and attractive force in conjunction determine how much space that material substance fills (volume); and density is simply the relation between the amount of material substance and the volume occupied by that substance, which determines the intensity of the real in that space. Although attractive force (which, recall, is proportional to the amount of material substance) does not vary in different material substances, repulsive force does, so the same quantity of different material substances will fill different amounts of space and therefore lead to different densities; and that is the end of it - no circle.

It might be thought that Westphal's version of the circularity problem still goes through because despite its superficial similarity to Förster's version of the circularity problem, it is couched in terms of mathematical functions rather than in terms of causal relations. But this is not so. Westphal is correct that the force of

65 Westphal, 2004, 196. 
attraction is proportional to mass; he is correct that within a given volume mass is proportional to density; and he is correct that it may be inferred from this that within a specific volume, the force of attraction can be determined as a function of density. But this is simply a result of the fact that if volume is held fixed, the function that maps mass to density is a bijection; importantly, it does not show that there is any conflict with Kant's official view, according to which density is a function of the balance of the two basic forces. This should be clear from the fact that if the stricture on holding the volume fixed is removed, then it is no longer the case that mass is proportional to density (a single mass value can map to different densities if it is spread over different volume values and a single density value can map to different mass values for the same reason). Speaking in terms of mathematical functions (rather than causal relations) adds some flexibility to the discussion and actually to some extent reflects Kant's concerns more accurately. The problem for Kant's critics (and Kant's criticism of himself, it seems) is that it also reveals that the supposed circularity, although tempting, is specious.

\section{Conclusion}

In the preceding, I have tried to defend Kant's theory of density from the circularity problem. Does this mean that I disagree when commentators argue that the circularity problem induced Kant (at least in part) to begin the project contained in the publication now known as the Opus Postumum? No. As has been seen above, Kant himself seems to have been persuaded (at least at one point in his life) that the circularity problem was genuine. And if Kant thought that the circularity problem was genuine, then it very well might have prompted him to try to develop a new theory of matter - and that certainly is part of what he does in the Opus Postumum. I do not take myself to be in a position here to weigh in on the vexed question about what might have led Kant down this road. What I take myself to have shown in this paper - or, at any rate, what I have tried to show in this paper - is that Kant's theory of matter in the MFNS is interesting, worth grappling with and perhaps underestimated even by Kant himself. 